\title{
AS EXPERIÊNCIAS INICIAIS DE ORGANIZAÇÃO POLÍTICO-SINDICAL DO NOVO OPERARIADO BRASILEIRO: O CASO DOS OPERÁRIOS CALÇADISTAS NO ESTADO DA BAHIA
}

\author{
LAS EXPERIENCIAS INICIALES DE ORGANIZACIÓN POLÍTICO- \\ SINDICAL DE LA NUEVA CLASE OBRERA BRASILEÑA: EL CASO DE \\ LOS OBREROS CALZADISTAS EN EL ESTADO DE BAHIA
}

Cristiano Ferraz

Universidade Estadual do Sudoeste da Bahia - UESB

\begin{abstract}
Resumo
$\mathrm{O}$ artigo trata das experiencias iniciais de organização político-sindical de um segmento do novo operariado brasileiro no Sudoeste da Bahia, entre 1998 e 2011. Analisa o processo de constituição de tais ações políticoorganizativas, seus impasses e resultados durante $o$ período delimitado.

Palavras-chave: Trabalho. Classes Sociais. Sindicalismo.

\section{Resumen}

El artículo aborda las experiencias iniciales de organización político-sindical de un segmento de la nueva classe obrera brasileña en el suroeste de Bahía, entre 1998 y 2011. Analiza el proceso de constituir tales acciones político-organizativas, sus impases y resultados durante el período definido.
\end{abstract}

Palabras clave: Trabajo. Clases Sociales. Sindicalismo.

\begin{tabular}{|l|l|l|l|l|l|}
\hline Revista RBBA & ISSN 2316-1205 & Vitória da Conquista & V.8 n ${ }^{\circ} 2$ & p. 57-79 & Dezembro/2019 \\
\hline
\end{tabular}


Introdução

(...) É possível flagrar a brutalidade das relações de trabalho e meio ambiente de trabalho nessas cidades. Em Ipirá [Bahia] os dirigentes que se recusaram a proposta de implantação do banco de horas tiveram que trabalhar aos sábados, capinando as áreas externas da fábrica. Um deles se viu forçado a atender à solicitação de sua família para abandonar o sindicado, pois estava sendo ameaçado. Em serrinha, a equipe do Projeto [projeto de pesquisa] teve que sair da cidade antes de concluir os trabalhos, pois estávamos sendo seguidos por um carro, como também por motoboys quando realizávamos a aplicação dos questionários com as trabalhadoras na saída do turno, na praça principal. Esses motoboys dispersavam os trabalhadores/as na saída do expediente, impedindo-as/os que formassem grupos. São os novos capatazes. Foi possível testemunhar o medo que toma conta da população dessas cidades onde estão sendo implantadas as fábricas. As indústrias se constituem numa esfera de poder no âmbito local, semelhante ao dos antigos coronéis dos tempos da República Velha. Petilda e Vanessa Seva Vazquez (VASQUEZ; VASQUEZ, 2007, p 11).

O tema do presente artigo são as experiências de organização do novo operariado brasileiro e deriva de estudo mais amplo sobre o tema (FERRAZ, 2008). O período delimitado para a análise vai de 1998 a 2011, que marca a primeira fase de mobilizações dos trabalhadores em um contexto também de primeira fase de organização do setor calçadista que engendra o novo operariado no Estado da Bahia. Os anos seguintes marcam abertura de um momento mais intenso de mundialização das grandes empresas calçadistas do Brasil, que significou, no caso em tela, em novos desafios para os sindicatos nos territórios do novo operariado brasileiro frente ao crescimento do desemprego e ao endurecimento das relações entre patrões e sindicatos.

A nova geração operária em questão surge em um contexto de mudança no padrão de acumulação do capital, que engendra transformações importantes na organização da produção de mercadorias. O fenômeno demonstra, mais uma vez, a velha tendência do processo de produção capitalista expressa na ação dos agentes da burguesia organizada que, diante das contradições sistêmicas que impedem a manutenção da taxa de lucro, elaboram novas maneiras de elevação da produtividade do trabalho vivo com vistas a potencializar um nível mais elevado de exploração da mais-valia do trabalhador. A emergência destes segmentos de 
trabalhadores e as novas plantas industriais que eles operam indicam uma nova fase capitalista (CHESNAIS; DUMENIL, 2003), inclusive na formação social brasileira.

A mudança é acompanhada por outra tendência histórica no processo de produção capitalista, que é a expansão da sua teia ocupando novas regiões. No Brasil, isso pode ser ilustrado pela migração de empresas industriais para áreas sem tradição fabril, como se observa no deslocamento de indústrias do Sul e Sudeste para o Nordeste do país, bem como na instalação de novas plantas em regiões sem tradição industrial no próprio Sul e Sudeste, além do Centro-Oeste. A nova forma social de organizar a produção de mercadorias engendra no Brasil um operariado estruturalmente diferente do trabalhador coletivo forjado na tradição fordista de produção e rotinização do trabalho. As novas fábricas incorporam, por exemplo, conceitos de produção e de gestão substantivamente diferentes daqueles observados nas tradicionais grandes indústrias do $\mathrm{ABC}$ Paulista que nos remete a um período do desenvolvimento industrial brasileiro, caracterizado, segundo Humprhey (1982, p. 58), por ter grandes empresas nas cidades industriais, e pela concentração de produção entre uma pequena quantidade de firmas de capital estrangeiro. Atualmente as grandes empresas não somente descentralizam a produção para áreas sem tradição industrial em seus ramos de atuação, como também descentralizam a própria produção ao incorporarem de forma terceirizada no processo outras empresas que atuam diretamente no chão-da-fábrica e que se coresponsabilizam com os resultados. Isso pode ser comprovado pela experiência dos consórcios modulares e condomínios industriais (Resende-RJ e Camaçari-Ba), que operam utilizando-se de níveis significativamente mais altos de automação e terceirização combinados com relações entre capital e trabalho que primam por um nível mais baixo de direitos, proteção social e de remuneração dos operários. Os exemplos citados representam as chamadas "fábricas enxutas", onde a produtividade supera a das fábricas fordistas tradicionais ou em vias de transição para o pós-fordismo (RODRIGUES; RAMALHO, 2007).

Do ponto de vista das determinações estruturais de classe, temos aí um substrato econômico que diferencia na forma e no conteúdo as realidades dos trabalhadores nas indústrias tradicionais e nas chamadas "fábricas enxutas". No campo político e cultural veremos também que existem elementos que diferenciam os trabalhadores das duas realidades em questão. Embora Rodrigues, Ramalho, Pontes e Santana (RODRIGUES; RAMALHO, 2007) indiquem mais semelhanças do que diferenças entre as duas realidades e argumentem de que não se trata de uma nova classe operária nos chamados greenfields e de uma velha 

NOVO OPERARIADO BRASILEIRO: O CASO DOS OPERÁRIOS CALÇADISTAS NO ESTADO DA BAHIA

classe operária nos browfields, no caso o Sul Fluminense e ABC Paulista, respectivamente, diríamos que as determinações estruturais em ambas levam a uma convergência que afirma a existência de um novo operariado. Se este constitui ou não uma classe social é outra questão, como veremos. Fato é de que, se no $\mathrm{ABC}$, a emergência desse novo operariado está relacionada ao fenômeno geral que produz os processos de reorganização da produção, de retirada de direitos e de estabelecimento de uma nova sociabilidade entre capital e trabalho que, à sua maneira, procura reduzir o patamar de conflitos entre patrões e operários em favor de uma relação sindical em que a cooperação e o caráter propositivo assumem destaque, no Sul Fluminense essa tendência se manifesta de maneira mais acabada por outras vias: trabalhadores sem tradição no que concerne ao embate sindical em seus ramos de atividade, indústrias que já se instalam nos marcos da produção enxuta, salários mais baixos etc.

As características identificadas com a velha geração operária do $\mathrm{ABC}$ estão em declínio. As suas determinações econômicas se metamorfoseiam, como também o seu modo de vida, ação política e cultura em uma unidade materialmente determinada pela fase capitalista que engendra um contexto histórico diferente daquele que se constituiu a partir dos anos 50, quando a Willys Overland (atual Ford) e outras montadoras migraram para são Bernardo do Campo. O fenômeno atual se assemelha à situação examinada por Gramsci no clássico Americanismo e Fordismo, quando dizia que "no industrialismo a hegemonia vem da fábrica". Muitos tomaram essa assertiva como uma avaliação de que o operariado industrial faria a revolução socialista. Mas o alcance da análise de Gramsci, embora considerasse essa possibilidade, não apontava necessariamente nessa direção. O revolucionário italiano referiase ao fato de que, no modo de produção capitalista, as relações de trabalho, os costumes, a aparelhagem estatal, a sociabilidade e as próprias representações elaboradas sobre o modo de vida são profundamente influenciadas pelas demandas e formas assumidas pela moderna organização da produção capitalista. Não é demais frisar que tais demandas e formas de organização da produção não brotam do nada, mas das necessidades políticas e ideológicas apresentadas pela burguesia, a classe social hegemônica.

Os princípios que brotariam da organização da produção material se refletiriam inclusive nos conteúdos técnicos e ético-políticos do trabalho em geral. Décadas se passaram 
desde a análise de Gramsci sobre o industrialismo americanista. Atualmente, outra mudança estrutural ocorre no modo de produção e, mais uma vez, a burguesia organizada em classe procura redefinir as bases político-ideológicas e culturais do seu projeto de sociedade, metamorfoseando a sua hegemonia. Essa nova hegemonia produz impactos negativos no modo de vida dos trabalhadores na medida em que aponta para precarização do trabalho e das dimensões políticas e institucionais que se relacionam com essa atividade. A presente hegemonia se manifesta de maneira mais plena onde as suas possibilidades de avanço são mais concretas, como se pode observar, por exemplo, em Resende com consórcio modular da Volkswagen e em Porto Real com a PSA Peugeot (cidades do Rio de Janeiro), na Camaçari do Complexo Ford (Bahia) ou Itapetinga dos operários da Azaléia (Bahia), na cidade paulista de Sumaré impactada com a fábrica da Honda ou em Catalão, em Goiás, onde a Mitsubishi monta caminhonetes. As fábricas mencionadas exemplificam uma tendência histórica sob o capitalismo, que é a tentativa de elevação da subsunção do trabalho pelo capital. Isso significa a existência de trabalhadores mais adequados às formas pós-fordistas de valorização do capital, com práticas políticas diferentes daquelas que se constituíram ao longo de décadas nas regiões industriais mais antigas.

Para verificar essa hipótese, a pesquisa foi realizada com operários do setor automotivo e calçadista. A escolha dos setores foi motivada por três aspectos. Em primeiro lugar por estarem diretamente ligados ao processo de mundialização do capital, o que os relaciona com as tendências mais gerais do setor fabril em nível internacional. Segundo, por que são setores que atravessam um expressivo processo de reorganização da produção e grande mobilidade espacial a partir da segunda metade dos anos 90, acompanhando a tendência que se verifica em diversos países do núcleo orgânico, bem como os periféricos e semiperiféricos do sistema interestatal (ARRIGHI, 1997). Em terceiro porque, apesar das semelhanças acima citadas, tradicionalmente são ramos bem diferenciados quanto ao tipo de mercadoria produzida, nível tecnológico, processo de produção e perfil operário.

No princípio da pesquisa estes aspectos foram delimitados como necessários para pôr à prova a hipótese sobre o surgimento de um novo operariado no Brasil. O objetivo era verificar a possibilidade de elementos de universalização em setores tão distintos quanto o calçadista e o automotivo. Para isto, examinaremos a experiência de trabalhadores do setor calçadista no interior da Bahia, a partir da instalação de uma grande empresa do setor naquela região, a Azaléia Calçados, no final da década de 90 do Século XX. Os trabalhadores em \begin{tabular}{l|l} 
Revista RBBA & Revista Binacional Brasil Argentina
\end{tabular} 

NOVO OPERARIADO BRASILEIRO: O CASO DOS OPERÁRIOS CALÇADISTAS NO ESTADO DA BAHIA

questão representam uma amostra do novo segmento do operariado nacional que surge com o fenômeno contemporâneo de instalação de plantas fabris com novos conceitos técnicoorganizacionais fora do tradicional eixo industrial do Sul e Sudeste do país, em um novo ciclo da industrialização brasileira (FERRAZ, 2008). O fenômeno citado demonstra, ainda, em nível regional e local, a manifestação de tendências mais gerais no modo de produção capitalista, no sentido de reorganizar a produção e estabelecer patamares mais intensos de exploração do trabalho em locais onde ainda não existe uma tradição consolidada de organização operária, a exemplo do que ocorreu em locais de industrialização mais antiga. A intenção dos capitalistas do setor é superar os limites impostos pelas formas de reprodução ampliada do capital que predominaram em escala mundial entre o II Pós-Guerra e final dos anos 70. Esta lógica está presente no atual deslocamento geográfico, conjugado à reorganização das estratégias de produção de diversos setores integrados à competição mundializada, como por exemplo, o calçadista.

\section{Dinâmica Capitalista e o Novo Operariado do Setor Calçadista}

Em finais da década de 90 do século passado, diversas indústrias calçadistas abriram plantas industriais no Estado da Bahia, na maioria das vezes em municípios onde sequer existiam fábricas até então. Dentre as indústrias envolvidas no processo, destaca-se a Calçados Azaléia S. A., gigante do setor calçadista que opera em escala mundial. A empresa começou suas atividades em 1958, na cidade de Parobé, Região Metropolitana de Porto Alegre. Atualmente é a maior indústria calçadista da América Latina e uma das maiores do mundo, e exportada para 40 países. Todas as suas marcas são ainda comercializadas no mercado nacional. A Azaléia Calçados fornece ainda componentes para grandes marcas de material esportivo. Além das plantas de Parobé-RS e da Bahia, a Azaléia possuía ainda uma fábrica em Sergipe.

A empresa começou a instalar suas fábricas no interior da Bahia em 1996, em pequenas cidades sem nenhuma tradição industrial, a aproximadamente $580 \mathrm{Km}$ de Salvador. Ali passou a operar uma rede produtiva composta por 25 unidades descentralizadas em torno

\begin{tabular}{l|l} 
Revista RBBA & Revista Binacional Brasil Argentina
\end{tabular} 
da fábrica processadora do produto final. Todas as unidades menores localizavam-se em pequenas cidades (sua população gira em torno de 20 mil habitantes) das regiões Sudeste e Sudoeste do Estado. Essas pequenas cidades espalham-se por um raio de cerca de $200 \mathrm{Km}$ em torno da matriz localizada no município de Itapetinga, cidade tradicionalmente ligada à pecuária de corte. A maioria das unidades que compõem a rede produtiva da Azaléia encontrava-se em municípios pobres - a exceção é Itapetinga - com grande contingente populacional transitando por empregos de baixa remuneração no comércio incipiente e na atividade agropecuária. No início das atividades da empresa, a previsão divulgada era é de que a rede de unidades produtivas da Azaléia geraria cerca de 10.000 empregos diretos quando estivesse funcionando plenamente. Em 2008 ocupava mais de 12.000 trabalhadores.

A Azaléia abriu suas fábricas na Bahia quando a indústria nacional já se encontrava em plena reorganização sistêmica da produção, em um processo de transição de paradigma industrial que nos permite integrá-la ao modelo do Padrão de Acumulação Flexível (HARVEY, 1996). Na Bahia, a referida empresa já começou a operar com base neste novo paradigma, não houve ali a conflituosa transição entre empresa e operários que ocorreu em seu local de origem. Ela adotou imediatamente estratégias de ação, processos de trabalho e relações com os trabalhadores que se diferenciam substantivamente dos modelos usualmente praticados no Rio Grande do Sul, a exemplo das formas de contratação, terceirização, de qualificação da força de trabalho, formas de relacionamento com os sindicatos e níveis de remuneração - significativamente mais baixos.

Um dos motivos declarados para o deslocamento da empresa é a necessidade de elevação da competitividade na atual fase capitalista, o que a levaria a buscar custos operacionais mais baixos e que passam, sobretudo, pela redução de salários e direitos trabalhistas, bem como pela realização do processo produtivo com um número significativamente menor de trabalhadores em relação à quantidade e qualidade de mercadorias produzidas. Contribuiria também para a relocalização industrial as chamadas "pressões corporativas" do movimento sindical no Vale dos Sinos, aonde a reestruturação produtiva proposta pela empresa enfrentou a resistência dos trabalhadores organizados, que se contrapôs a redução dos salários e à supressão de direitos trabalhistas.

No Sudoeste da Bahia a Azaléia é a primeira grande fábrica. Na grande maioria das cidades que fazem parte da sua estratégia produtiva em rede ela é a primeira e única fábrica existente. Para a Azaléia as vantagens foram muitas. Inicialmente a empresa contou com a 

NOVO OPERARIADO BRASILEIRO: O CASO DOS OPERÁRIOS CALÇADISTAS NO ESTADO DA BAHIA

ausência de uma tradição de sindicatos combativos. Além disso, obteve expressivos incentivos fiscais, dentre as empresas calçadistas que migraram para a Bahia no final dos anos 90, a Azaléia foi a que mais se beneficiou de benefícios dessa natureza. A empresa recebeu ainda grandes financiamentos para suas estruturas, a taxas e prazos extremamente favoráveis. Isto contribuiu de forma importante para a redução do custo da empresa com capital inicial. $\mathrm{Na}$ Bahia o estado arcou inclusive os custos do treinamento dos operários no Senai.

$\mathrm{Na}$ Bahia, as fábricas do setor calçadista se destacam por oferecer um péssimo tratamento aos operários. No caso da Azaléia, o despotismo fabril e a brutalidade das relações entre capital e trabalho se revelam ainda no alto índice de operários mutilados. Segundo informações do Sindicato de Trabalhadores de Calçados de Itapetinga e Região, desde que a empresa começou a funcionar, 82 operários já perderam falanges, dedos, mãos e antebraços. Isto sem contar as lesões causadas por Lesões por Esforço Repetitivo - LER, bursite e hérnia de disco (RIBEIRO, 2008). O que se vê ali é uma síntese contraditória entre o que há de mais avançado em termos de processos de produção com formas de tratamento dos trabalhadores que lembram as relações entre capital e trabalho dos Séculos XVIII e XIX. Isto pode ser demonstrado pelo exemplo de um dos últimos acidentes que registramos na pesquisa que dá origem ao presente artigo, quando um operário da Azaléia perdeu a falange de três dedos da mão em uma prensa. Na ocasião o diretor de recursos humanos alegou que a máquina era segura e sugeriu que a culpa pelo acidente foi do operário, que se descuidou. Segundo o diretor de RH, "o posto de trabalho é seguro. É uma máquina italiana que atende todas as normas de segurança europeias" (RIBEIRO, 2008). Em contrapartida, o operário argumentou que o acidente foi causado por causa das metas de produção cobradas pela empresa. As metas sobrecarregavam todos na fábrica e exigia dos operários um ritmo de trabalho tão acelerado que, por vezes, era necessário tentar superar o ritmo da máquina. Assim, na operação com a prensa, o braço mecânico da máquina não retirou todos os resíduos da matéria prima e o operário resolveu dar mais agilidade ao processo retirando manualmente o material, a mutilação ocorreu naquele momento. O operário explicou a situação da seguinte maneira: “Trabalhamos sob pressão psicológica. Se não conseguirmos atingir a meta de produção somos penalizados com demissão por justa-causa e com advertência” (RIBEIRO, 2008). 
Somando-se ao ritmo intenso e à pressão psicológica, existe ainda o problema do assédio moral por parte da empresa. Segundo o presidente do sindicato, "se o funcionário for três vezes ao banheiro e quatro vezes ao bebedouro durante o turno, o gerente acusa de estar fazendo corpo mole" (RIBEIRO, 2008). Na ocasião deste último acidente citado, a Azaléia foi notificada pelo Centro de Estudos da Saúde do Trabalhador - CESAT, órgão vinculado à Secretaria de Saúde do Estado da Bahia - SESAB, que sugeriu pausas para descanso e revisão das metas de produção da empresa.

Mas, aquele não foi um fato isolado. Em 2000, o CESAT alertava sobre as condições de trabalho na Azaléia. Com base em inspeções realizadas em julho 1999 e outubro de 2000, cujo objetivo era mapear riscos para os trabalhadores, a análise do órgão governamental taxativa: na maioria absoluta dos postos de trabalho na fábrica da Azaléia em Itapetinga as condições de trabalho eram insalubres e contrariavam as normas de segurança previstas pela legislação, era preciso realizar uma intervenção imediata para a solução dos problemas. Os trabalhadores estavam expostos ao calor, vapores tóxicos e manuseavam produtos químicos perigosos sem proteção; os níveis de ruídos extrapolavam os patamares de segurança; os operários realizavam o trabalho sem equipamentos de proteção tais como luvas, máscaras e calçados adequados à realização das tarefas; os procedimentos de segurança na operação das máquinas não eram suficientes e a ergonomia favorecia o surgimento de doenças (BAHIA. Governo do Estado da Bahia, 2001). Enfim, as condições de trabalho não eram adequadas em 1999-2000 e continuava da mesma maneira 10 anos depois. Situação semelhante era observada nas outras empresas do setor no Estado da Bahia, o que demonstra que nas novas plantas industriais este tipo de situação não era uma exceção, mas uma característica recorrente.

O nível de exploração era tal, que o centro das reivindicações dos trabalhadores e sindicatos na Bahia é de que as suas condições de trabalho sejam igualadas às dos operários da empresa no Rio Grande do Sul, apesar das perdas de benefícios e direitos que os operários do Sul acumularam com o processo de reestruturação produtiva que tomou curso nos anos 90 . Este foi o primeiro objetivo estabelecido pelo sindicato que representa os operários da Azaléia na Bahia. Uma meta que supõe a redefinição mais geral das estratégias de produção e de mercado da empresa, haja vista que é sobre esta condição de diferenciação que a Azaléia procurou incrementar a sua competitividade nos mercados nacional e internacional. Isto porque, desde finais dos anos 80 , um dos objetivos que a empresa perseguia com a instalação

Revista RBBA $\mid$ Revista Binacional Brasil Argentina 

NOVO OPERARIADO BRASILEIRO: O CASO DOS OPERÁRIOS CALÇADISTAS NO ESTADO DA BAHIA

de novas plantas fora do seu tradicional eixo industrial era aproximar-se das concorrentes asiáticas em termos de custos com a força de trabalho, substancialmente mais baixos do que aqueles praticados nas áreas em que o setor calçadista brasileiro operava até então.

\section{Formas de Resistência e de Organização do Novo Operariado}

Os trabalhadores da Azaléia começaram a se organizar politicamente em 1998, inicialmente em reuniões com pequenos grupos para discutir a situação de trabalho e a necessidade de pensarem formas de se contraporem à acentuada exploração a que se viam submetidos. A organização sindical dos operários tem início em 1999, quando registram um sindicato. O processo se dá sob influência inicial da militância do PC do B na cidade, posteriormente o PT torna-se o partido hegemônico entre os membros da diretoria. $\mathrm{O}$ sindicato nasce filiado à CUT e com a denominação Sindicato de Verdade. Atualmente representa os operários calçadistas de Itapetinga e Região e sua base concentra-se na Azaléia. Inicialmente, em 1997, a representação sindical dos trabalhadores da Azaléia cabia ao Sindicato dos Trabalhadores nas Indústrias de Tecelagem e Fiação do Estado da Bahia Sinditextil. O Sindicato dos Trabalhadores nas Indústrias de Artigos de Borracha e Afins Sindborracha disputava a base com o SindTextil. O argumento dos dois sindicatos era de que nas novas fábricas as matérias primas com as quais os operários trabalham os enquadrariam nos ramos de atividade dos seus respectivos setores de representação.

Em 2007 os sindicatos dos operários calçadistas da Bahia se fundiram em uma federação. Segundo diretores do Sindicato de Verdade, a ideia era constituir um sindicato único, um "sindicatão", como os operários se referiam. Divergências entre alguns dos sindicatos dificultaram o processo. Atualmente somente um deles não se encontra abrigado na federação. Integra ainda a federação o Sindicato dos Trabalhadores nas Indústrias e Empresas de Fabricação, Produção, Montagem e Acabamento de Calçados em Geral do Município de Jequié e Região - Sintracal. O Sintracal representa os trabalhadores da Dass Clássico (Dilly e Clássico do Nordeste) e Ramarim, em Vitória da Conquista e Jequié. Cobre ainda a base em outros municípios da Bahia, tais como Santo Estevão - próximo de Feira de Santana - Rui Barbosa, Conceição do Coité, Serrinha, Santo Antônio de Jesus e outros. Em Jequié, o 
Sintracal começou a atuar inicialmente na Ramarim, em 1998. Atualmente o Sintracal dirige a Federação do setor.

Os trabalhadores da Azaléia no Vale dos Sinos e na Bahia se organizam em campos sindicais distintos: enquanto na Bahia o seu sindicato é cutista, no Rio Grande do Sul integrava a Força Sindical e atualmente é filiado à Nova Central Sindical de Trabalhadores NCST. As diferenças entre as duas perspectivas sindicais são amplamente conhecidas e diversas pesquisas tratam do assunto (TRÓPIA; MARCELINO; GALVÃO, 2015). Por hora é suficiente dizer que a Força Sindical representa o braço neoliberal no movimento sindical brasileiro (TRÓPIA, 2002; GALVÃO, 2007). Os sindicalistas do setor calçadista na Bahia têm, inclusive, muita clareza sobre o papel desempenhado pela Força Sindical. Na ocasião de constituição do sindicato em Itapetinga, chegaram mesmo a recusar o diálogo inicial com o sindicato do Sul. A proposta de diálogo foi feita por representantes da empresa, que teria relação mais próxima com os sindicalistas da Força Sindical do que com aqueles ligados ao campo cutista.

A criação do sindicato não foi fácil. A repressão da empresa foi intensa e os trabalhadores temiam serem vistos em qualquer tipo de reunião que não fosse destinada a atividades de lazer. Temiam ainda serem vistos com outros operários que já se colocavam em oposição às práticas da empresa e dos seus prepostos. Mas, apesar de todo o clima de tensão que girava em torno do tema da organização sindical, existia também entre o conjunto dos operários a ideia de que era preciso tentar se organizar. Tal ideia começou no "boca-a-boca", em conversas de boteco, no futebol e reuniões nas casas de alguns operários. Os trabalhadores que estavam mais à frente da questão tiveram contato com representantes de outros sindicatos, tais como o Sindicato dos Bancários e APLB - Sindicato dos Trabalhadores em Educação da Bahia, e se instruíram sobre os passos necessários. A maior dificuldade era realizar a assembleia de fundação, onde seria produzida a ata de criação da entidade e eleita sua primeira diretoria. O passo seguinte seria buscar o registro sindical junto ao Ministério do Trabalho.

Por experiência anterior, os operários já sabiam que qualquer reunião com esse fim resultaria em demissão imediata para os seus participantes. Naquela conjuntura, a dificuldade inicial para reunir os trabalhadores e realizar a assembleia de criação parecia um obstáculo intransponível. Como Itapetinga não era uma grande cidade, ficaria relativamente fácil para a empresa mapear qualquer movimentação "anormal" por parte dos trabalhadores. Isto inclusive 

NOVO OPERARIADO BRASILEIRO: O CASO DOS OPERÁRIOS CALÇADISTAS NO ESTADO DA BAHIA

já havia acontecido antes, quando um grupo de trabalhadores foi demitido ao começar a falar sobre a necessidade de criação de um sindicato e fazer um discurso mais reivindicativo no chão-da-fábrica. No entanto, entre os operários, se por um lado, havia o ambiente de repressão, por outro lado, existia também um sentimento de esperança por saberem alguns colegas estavam se engajando novamente na criação de um sindicato.

O ano era 2000, o processo de criação do sindicato já havia sido desencadeado, a percepção entre os líderes da iniciativa era de a empresa descobriria rapidamente, até porque não seria possível manter em segredo uma movimentação que crescia entre os operários. Era preciso dar celeridade ao processo. A solução para o problema da assembleia não tardou, foi criativa e se adaptou às circunstâncias: o sindicato começou a ser criado em uma festa dos trabalhadores. Segundo o depoimento de Tenório Lima, um dos fundadores do sindicato, a ideia também era mostrar para os operários que, dessa maneira, empresa poderia ser despistada. Foi feita uma convocatória para a reunião e para a festa do $1^{\circ}$ de Maio de 2000 , no Sindicato dos Bancários de Itapetinga, animada por um forrozeiro. A ideia era de que fosse

Uma festa promovida, não pelos trabalhadores da Azaléia, mas pelos sindicatos da cidade, APLB, Sindicato dos Bancários... em comemoração ao Primeiro de Maio! A gente faz uma convocatória e para ter direito [à festa e à assembleia] tem que trazer o crachá (Transcrição de entrevista, 2008).

Mais de 100 operários compareceram à comemoração, após meia hora de festa os trabalhadores que estavam se articulando para a criação do sindicato baixaram o som e anunciaram que naquele momento se realizaria a assembleia para a criação do sindicato. Alguns trabalhadores temeram continuar na atividade em virtude do grande número de pessoas de outras categorias que ali estavam e que poderiam comentar sobre o evento, de modo que assim a direção da empresa pudesse, talvez, identificar os nomes daqueles que estavam presentes e demiti-los. As pessoas que estavam mais à frente do processo e que se apresentaram como candidatos para primeira chapa do sindicato convenceram os colegas a permanecerem para a assembleia e argumentaram que 
O nome de ninguém ia vazar, a gente vai pegar tudo isso aqui, as atas etc, e tudo vai para o Ministério do Trabalho, vai para Brasília, eles [prepostos da empresa] não vão ter acesso a isso, a única coisa que iam saber era do edital, que vai sair no Diário Oficial da União, com o nome não de vocês, mas como os nossos nomes, os nomes de quem vai fazer parte da diretoria,(...) mas, muitos saíram [da assembleia] com medo. (Transcrição de entrevista, 2008).

O segredo continuou no dia seguinte a realização da assembleia. Os que estavam na festa olhavam os novos representantes com esperança, "como se alguma coisa fosse acontecer":

Quem estava na festa e sabia nos olhava com outros olhos, mas no resto da fábrica ninguém sabia de nada. $\mathrm{O}$ pessoal nos olhava com esperança, entendeu? "Ôpa, e aí Tenório? E aí Sílvio? E aí Andrea? [primeiros diretores do sindicato] E aí?" Era esperança, esperança mesmo, tipo "pelo menos agora vai ter alguém que brigue pela gente, quem nos defenda". (Transcrição de entrevista, 2008).

Mas, isto se restringia ao grupo da assembleia, a maioria dos trabalhadores ainda não sabia que o processo legal para a criação do sindicato já estava em curso. A informação não vazou, só foi revelada cerca quatro meses depois, quando saiu o registro sindical da entidade. $\mathrm{Na}$ ocasião toda a diretoria provisória foi à diretoria da empresa levar o Diário Oficial com a publicação do registro sindical. Perguntando sobre a reação da empresa, Tenório Lima relatou:

Rapaz... foi de susto, foi engraçado. No primeiro momento eles não quiseram nos atender, não nos atenderam, a gente estava com o pessoal do $\mathrm{PC}$ do $\mathrm{B}$ e eles disseram que não aceitariam conversar com ninguém de fora, com o pessoal do PCdoB, disseram que só conversariam conosco, só com os próprios funcionários, só com o pessoal que estava lá como diretor sindical, com o pessoal do PC do B eles não queriam conversa. E assim foi feito, e a gente não foi para o setor administrativo, fomos para um galpão um galpão que servia de depósito, onde estavam todos os gerentes, inclusive um gerente geral da produção, um "alemãozão" do Rio Grande do Sul, todos os gerentes! Eles fizeram um círculo e nós nos sentamos nesse círculo. (...) $\mathrm{Na}$ fábrica, esse "alemãozão" tinha o costume de falar em alemão com outros gerentes gaúchos quando o peão estava perto, para o peão não entender $o$ que eles falavam. Falava em alemão mesmo! Os cabeças eram esse "alemãozão" e outro gerente sergipano que veio de uma fábrica da Paraíba. (Transcrição de entrevista, 2008). 

NOVO OPERARIADO BRASILEIRO: O CASO DOS OPERÁRIOS CALÇADISTAS NO ESTADO DA BAHIA

O diálogo inicialmente foi aparentemente amigável, embora a gerência tentasse cooptar a nova direção do sindicato. O discurso velado era "venham para o meu lado, pois, do meu lado vocês vão ganhar... Contra mim vocês vão se danar”. Quando a diretoria provisória afirmou que eles estavam ali para representar os trabalhadores e de que não havia como ficar do lado da empresa a tensão começou a se manifestar abertamente. No mesmo período, um dos gerentes que encabeçavam as conversas iniciais com a diretoria do sindicado convidou Tenório Lima para conversar, afirmando as vantagens de alinhar com os objetivos da fábrica:

O discurso [do gerente] era de que "você é um cara capaz, você é o cara inteligente... fica se misturando com isso rapaz... venha para o meu lado...". Aí contava aquela história dele de que começou limpando privada, depois foi para linha de produção, depois virou multiplicador, que virou gerente e que hoje é um homem de não sei quantos mil reais, com casa não sei aonde etc, etc... tinha um discurso salvacionista, de que se eu seguisse os passos dele, por seu "uma pessoa inteligente, que se destacava no meio da multidão", que eu ia me dar bem. (Transcrição de entrevista, 2008).

Esse discurso era direcionado para o presidente do sindicato, um rapaz de 22 anos na época e para Tenório Lima (tesoureiro). Ambos formaram o grupo de articuladores iniciais do processo de criação do sindicato e continuaram na primeira diretoria. Inicialmente eram eles que "seguravam o discurso sindical". A tentativa de cooptação durou cerca de seis meses, a direção da fábrica usava as mais diversas estratégias, desde a tentativa de cooptação coletiva, ao trabalho de cooptação individual dos diretores do sindicato.

Eles tentam cooptar a gente, chamaram um a um dos diretores para cooptar. Primeiro eles me chamaram, porque eles acharam que eu era o cabeça né, e como eu passei bater pesado, comecei a ir para enfrentamento nesse sentido, e aquela coisa... digamos assim... o meu orgulho começou ficar ferido, porque eles queriam me comprar com pouco, se fosse dez bilhões de dólares, quem sabe né? [risos]! Mas não só a questão de comprar Tenório, era a questão de comprar a consciência de todos os trabalhadores da Azaléia, de fazer o sindicato pelego. E isso na minha concepção, dentro do processo de luta que a gente vivia, não passava pela minha cabeça. (Transcrição de entrevista, 2008). 
No diálogo com a diretoria do sindicato a empresa sempre se referia ao sindicato do Sul como um modelo de boas relações com a Azaléia.

Diziam que lá no Rio Grande do Sul, o sindicato tem uma sede maravilhosa para não sei quantos mil funcionários, com quadra poliesportiva, com piscina, consultório odontológico, consultório médico, tudo pago pela Azaléia! Teve uma reunião com Luiz Alberto, que era o administrador da fábrica... Que foi um vacilo meu. Eu tô trabalhando, aí daqui há pouco chega um e fala "ó, Luiz Alberto quer falar com você lá na administração", o que eu tinha que ter feito era ter chamado o presidente do sindicato, que trabalhava no mesmo pavilhão que eu, e no mínimo eu e o presidente deveríamos ter ido lá. Mas na agonia ali também... Na minha falta de experiência, sei lá... Nesse período eles chamavam direto para falar as maiores barbaridades possíveis... Assim, propunham uns absurdos tipo "vocês [da diretoria do sindicato] querem o quê, a gente ajuda vocês. Vamos, digam aí o que vocês querem", eu fui lá imaginando que era um negócio desses, mas na verdade o que eles queriam mesmo era me comprar com esse discurso de que o sindicato lá [Rio Grande do Sul] era assim e assado etc. Aí eu disse "olha, Sr. Luiz Alberto, a gente prefere trabalhar com o dinheiro dos associados", aí ele disse "mas vocês só tem cento e poucos associados", aí eu disse "mas é esse dinheiro que alimenta a nossa estrutura, fazer o quê?". Ele não ofereceu dinheiro, mas ele se ofereceu para construir uma sede e coisa e tal, ele disse que fizeram e aconteceram com o sindicato lá (no RS) e que queriam fazer a mesma coisa aqui, disse que tinha um terreno ali do lado, dentro da fábrica, disse "a gente tá precisando fazer uma clínica do trabalho aqui e aí a gente constrói lá para vocês, a gente bota do jeito que vocês quiserem, a gente faz uma clínica odontológica lá, coisa de primeiro mundo! Você quer creche? [a creche fazia parte da pauta do sindicato com a empresa] A gente faz uma creche aqui de primeiro mundo", etc, etc...

"Nunca eles me disseram, "olha eu vou dar um dinheiro pra você, eu vou comprar você..." "É associação, olhe só... É parceria! [reproduz fala do administrador da fábrica]". "Eles [os gerentes] falavam em parceria entre o capital e trabalho: "Pra quê que o capital e o trabalho têm que andar separado?!" Aí eu disse: "eu também acho, né? Não tem como, a gente tem que trabalhar....". Foi a primeira vez que ouvi esse termo na minha vida, capital/trabalho, foi dentro da Azaléia, capital/trabalho.... E aí, como eu reneguei, eu disse a ele que minha alma não estava à venda: "você tá querendo me comprar, você tá me achando com cara de besta?". Aí os ânimos se afloraram e ele me expulsou da sala dizendo: "Ah, então volta pra trabalhar!!”. Não me xingou não, só faltou me chamar de cabeçudo, mas não me xingou não, mas me expulsou da sala dele aos berros". (Transcrição de entrevista, 2008).

As informações que o administrador da fábrica dava sobre o sindicato casavam com aquelas que militantes do PC do B e do PT tinham dado aos membros da primeira diretoria. A diretoria da fábrica chegou a informar que traria o presidente do sindicato em Parobé para 

NOVO OPERARIADO BRASILEIRO: O CASO DOS OPERÁRIOS CALÇADISTAS NO ESTADO DA BAHIA

conversar com a diretoria do sindicato recém-criado, mas os trabalhadores recusaram a proposta.

As tentativas de cooptação tiveram fim, nessa primeira fase do sindicato, quando começou a primeira campanha da entidade em torno de uma pauta sindical, composta basicamente de reivindicações por melhores condições de trabalho, contra os maus tratos dos superiores, contra a extensão da jornada de trabalho e por melhores salários. Neste momento, o sindicato começou a sofrer não somente a pressão da empresa, mas também de setores importantes da comunidade, como demonstra o relato de um dos fundadores do sindicato:

A partir desse momento [quando começa a primeira campanha sindical], todas as rádios falavam "poxa, esses caras querem acabar com os empregos da Azaléia", no lugar que eu ia tomar café todo dia de manhã, as pessoas [da comunidade] me olhavam de cara feira. (Transcrição de entrevista, 2008).

$\mathrm{Na}$ fábrica a situação também ficou mais difícil para os operários que se envolviam com o sindicato:

\begin{abstract}
Logo no início a gente não conseguiu agregar [os trabalhadores]. Tirando aquelas pessoas mais próximas, aquele núcleo mais próximo, os amigos etc, era mais fácil da gente trabalhar. Eles [os demais operários] reconheciam o sindicato, mas a questão era a seguinte: o medo do peão da Azaléia era de perder o emprego, porque a partir desse momento [da primeira campanha sindical] a empresa começou a fazer o terrorismo, "olhe só quem se sindicalizar vai ser demitido", e era, eles faziam isso mesmo, porque a gente tinha que mandar a lista dos sindicalizados para que eles descontassem [a mensalidade sindical] em folha. Logo no início muita gente se filia, logo depois começaram a ser demitidas, demitidas... Se você falasse um "ai" e fosse sindicalizado, era motivo de demissão, eles priorizavam para demissão os sindicalizados, e diziam isso de forma bem clara, não era uma coisa velada, os gerentes falavam isso abertamente, quando brigavam com você eles falavam: "vá procurar o sindicato sacana, para você ver, vá lá procurar! Em mando você embora agora e tem quinhentos lá fora querendo entrar para ganhar metade do que você ganha". E aí o trabalho sindical foi um inferno. (Transcrição de entrevista, 2008).
\end{abstract}

Assim, expectativa inicial de que a situação melhoraria com a criação do sindicato encontrou uma série de obstáculos. Alguns partiam da própria condição dos operários, como 
por exemplo, a baixa participação nas ações do sindicato com receio de que os patrões os identificassem com a entidade e os demitissem.

Isto não impediu que os operários da Azaléia iniciassem suas lutas de forma mais organizada. A primeira greve ocorreu em 2000, quando os trabalhadores paralisaram a fábrica por uma semana. Em 2004 voltaram a paralisar as atividades por 12 dias. Em ambas as greves a pauta se constituía de pontos relacionados à melhoria das condições de trabalho e melhores salários.

Um traço que caracterizou todas as mobilizações do segmento baiano do novo operariado brasileiro em sua recente história foi a dura repressão que sofreram, não somente por parte da empresa, mas também pelas forças policiais do estado. A ação repressiva contra os trabalhadores somou-se o seu isolamento em relação à comunidade local. Em todas as mobilizações e greves a população se voltou contra os sindicatos e contra os trabalhadores. Pesou para isso a ação dos prefeitos, vereadores, empresários e imprensa local.

Em Itapetinga a situação foi emblemática. $\mathrm{Na}$ primeira e na segunda greve, empresários do comércio e vereadores organizaram passeatas na rua contra o movimento e chegaram a fechar o comércio da cidade em protesto contra a greve. Na segunda greve dos operários da Azaléia duas passeatas estavam programadas, um dos trabalhadores, organizada pelo sindicato, e outra novamente organizada pelos empresários do comércio, dessa vez incluindo outros segmentos da comunidade local. Em um dado momento as duas passeatas se encontraram em uma das praças do centro da cidade e a agressão física contra os operários tomou o lugar do diálogo e das palavras de ordem. Vários operários saíram machucados, alguns dirigentes do sindicato tiverem que sair da cidade porque foram ameaçados de morte. A polícia militar agiu com extrema truculência e apreendeu a filmadora utilizada pelo sindicato para registrar a mobilização. De um modo geral, as rádios e TVs silenciaram sobre o fato e não deram voz aos trabalhadores, como se quisessem ocultar em uma cidade de cerca de 80.000 habitantes que a maior fábrica do interior da Bahia ali localizada estava paralisada e os trabalhadores se encontravam protestando nas ruas. De acordo com o depoimento que nos foi dado em 2008 por Roberval Medrado de Oliveira, um dos diretores do Sindicato, até aquele momento militantes do sindicato ainda sofriam ameaças por parte de policiais. Segundo ele, em três ocasiões teve "sair fugido da cidade para não morrer". Oliveira, evita frequentar as festas públicas na cidade por receio de represálias de policiais. 

NOVO OPERARIADO BRASILEIRO: O CASO DOS OPERÁRIOS CALÇADISTAS NO ESTADO DA BAHIA

\section{Considerações finais}

A repressão sofrida pelos trabalhadores da Azaléia demonstra também outro dado evidente: a ação reivindicatória dos operários. Nesse sentido, não somente entre os operários calçadistas aqui pesquisados, mas também no conjunto dos operários calçadistas do Nordeste, os trabalhadores da Azaléia estavam entre aqueles que possuem um maior nível de organização sindical e de ganhos, tomando-se como referência temporal o período delimitado no presente artigo. Tomando-se como referência as fábricas pesquisadas, os trabalhadores da Azaléia eram os únicos que até 2009 haviam obtido auxílio educação (cerca de R \$ 80,00 divididos em duas parcelas durante o ano) e auxílio funeral. Obtiveram auxílio creche, além da Participação nos Lucros e Resultados - PLR. Na Ramarim, em Jequié, não havia o auxílio educação. As negociações a partir dos parâmetros dos trabalhadores da Azaléia fizeram com que os operários conquistassem aquele tipo de auxílio. A média salarial também era maior na Azaléia do que nas outras fábricas calçadistas. Em 2009, os salários dos operários da empresa iam de $\mathrm{R} \$ 470$ à $\mathrm{R} \$ 550,00$, sendo que o piso era de $\mathrm{R} \$ 415,00$, correspondente ao salário mínimo vigente na época (2008). Na Dass Clássico e na Dilly o salário era $\mathrm{R} \$ 425,00$ e correspondia ao piso naquelas fábricas. No restante das fábricas, na Bahia e nos outros estados do Nordeste, o salário correspondia ao "piso do Governo", como os operários se referiam ao salário mínimo. Enquanto nas outras fábricas ainda existia o banco de horas, na Azaléia o sindicato conseguiu negociar com a empresa a sua extinção. Entretanto, o banco de horas continua para os trabalhadores terceirizados, que realizam o trabalho fora da produção ou, como dizem os operários, aqueles que "não pegam no tênis". Atualmente, na Azaléia, quando a fábrica paralisa uma linha a produção de determinada linha de produtos o operário fica parado sem desconto salarial e a reposição é negociada com o sindicato, caso a caso. Segundo os dirigentes do sindicato, as condições de segurança no trabalho também melhoraram muito, mas ainda continuam ruins. Atualmente a mídia tem dado algum espaço às constantes denúncias do sindicato sobre os acidentes recorrentes que causam mutilação. Em 2008, várias denúncias sobre as condições de trabalho na fábrica resultaram, no mês de agosto, na interdição de dois dos seus pavilhões por três dias pela Delegacia Regional do 
Trabalho de Vitória da Conquista. Os pavilhões voltaram a operar após decisão de um juiz da comarca de Itapetinga. Em algumas filiais, após ação do sindicato a partir de denúncias dos operários, a fábrica foi obrigada a utilizar adesivos à base de água na colagem dos componentes dos tênis. O novo produto é mais caro, mas, menos prejudiciais do que os adesivos à base de solventes. Posteriormente a empresa contratou ainda 16 técnicos de segurança do trabalho em Salvador, em cada filial passou a existir um técnico. Algumas máquinas foram substituídas ou modificadas para incorporar mecanismos de segurança mais eficientes. Para dar conta das tarefas nas filiais e na matriz, a diretoria do sindicato foi ampliada. Em quase todas as filiais passou a existir um diretor sindical.

Ao longo da pesquisa percebemos que a estrutura de trabalho do sindicato em Itapetinga melhorou. A casa em que foi instalado o sindicato foi reformada e em 2009 a entidade contava inclusive com um carro zero quilômetro para realizar o trabalho sindical. Mesmo em 2008, a estrutura era muito melhor do que a existente entre outros segmentos do novo operariado brasileiro, como se podia observar no caso Sindicato dos Metalúrgicos de Camaçari, que representava os trabalhadores do Complexo Ford naquele período.

De acordo com os dados do sindicato, a adesão à entidade também melhorou no período delimitado. Em 2010, nas filiais, em torno de 30\% dos operários eram filiados. Em 2010, o total de filiados ficava em torno de 2.700 trabalhadores. Segundo os diretores do sindicato, a filiação só não era maior por conta da rotatividade da mão-de-obra e em virtude da pressão da gerência para conter a adesão ao sindicato, principalmente nas filiais que ficam nas cidades menores. No que se refere à rotatividade, a empresa demitia em média 200 operários por mês, na lista de demissões os sindicalizados têm prioridade.

Outro dado importante naquele período inicial de organização sindical foi a melhora na relação do sindicato com a comunidade. E preciso dizer que isto ocorreu mais em virtude da comunidade ter contato com a real condição de trabalho dos operários do que a um processo de reversão da mentalidade anti-sindical. Os casos de esgotamento, de depressão e as mutilações passaram a ser cada vez mais conhecidos e acabaram contribuindo para aproximar sindicado e comunidade.

Do ponto de vista político, os dirigentes sindicais atuavam de forma mais organizada nos fóruns de debates e deliberações da CUT e militavam pela reativação da CUT Regional. As direções do sindicato eram vinculadas ao PT e participavam da corrente Reencantar, 

NOVO OPERARIADO BRASILEIRO: O CASO DOS OPERÁRIOS CALÇADISTAS NO ESTADO DA BAHIA

denominação ao qual se integravam os chamados "militantes independentes". Procuram ainda se distinguir da corrente Articulação Sindical, que julgam pouco combativa.

Em síntese, do ponto de vista das condições de trabalho os trabalhadores da Azaléia conquistaram uma condição "menos pior" - como eles dizem - do que os demais operários do setor na Bahia e nos outros estados do Nordeste. Em Vitória da Conquista, onde se encontra parte da base do SINTRACAL, a situação era mais delicada. Conforme informações colhidas entre dirigentes sindicais e operários, o SINTRACAL enfrentava mais dificuldades para fazer frente às demandas organizativas da sua base.

Apesar da situação dos trabalhadores da Azaléia ser "menos pior" do que a dos demais operários do setor, a empresa ainda é conhecida como Senzaléia, até porque os ganhos relativos conquistados pelos operários não os distinguem de forma significativa do conjunto dos demais trabalhadores calçadistas do Nordeste. Outra questão que deve ser considerada é o fato de que, embora a situação política do sindicato também tenha melhorado no contexto de Itapetinga e região, a resistência da comunidade ao sindicato ainda é muito presente.

No que diz respeito à receptividade do sindicato entre os operários, mesmo que tenham críticas à entidade, esta lhes afigura como a única trincheira de onde se pode fazer algo em defesa dos seus interesses. Nesse sentido as suas ações são valorizadas, mesmo quando são tímidas frente às demandas dos operários. Com relação aos sindicatos que atuam em outras empresas a avaliação é menos positiva. Isto pôde ser verificado em uma enquete operária e entrevistas realizadas entre 2008 e 2009. Em ambos os procedimentos de pesquisa, os dados indicaram que em outras empresas, como por exemplo, Dilly e Dass Clássico a posição dos trabalhadores é de que o sindicato "faz pouco por eles". No entanto, a partir dos próprios depoimentos percebeu-se que isso ocorre não só por causa das debilidades do sindicato, mas também pelo medo que os operários têm de se verem vinculados a alguma ação sindical e sofrerem represálias da empresa.

Embora exista uma pequena diferenciação entre os dados da enquete operária aplicada nas três fábricas (Dilly, Das Clássico e Azaléia), uma característica unifica os trabalhadores nas três situações: Trata-se da ideia comum de que o sindicato é quem deve fazer as lutas, foram eleitos para isso, "recebem para isso". No depoimento dos operários é possível 
identificar uma separação do tipo "nós e eles", como se houvesse uma espécie de "terceirização" da luta, que deve ser realizada pelo sindicato em nome dos trabalhadores, que não necessariamente se sentem comprometidos com esse tipo de ação. Evidentemente isto tende a mudar em situações limite, como por exemplo, no caso de uma greve. No entanto, quando eclode um movimento dessa natureza o operário individual demonstra se sentir oculto no seio da mobilização geral, até porque nestes momentos a ênfase maior é dada aos sindicalistas, tanto por parte da empresa, quanto por parte da comunidade externa. Fora dessas situações a participação dos trabalhadores é muito pequena.

Por fim, a maior preocupação do sindicato naquele período era a compra da Azaléia pela Vulcabrás em 2007, empresa do grupo Alpargatas. Isto porque, no Nordeste, a Vulcabrás tinha um histórico muito ruim no âmbito das relações com os sindicatos e com os trabalhadores. O receio do sindicato era de que a Vulcabrás implantasse na Azaléia uma política ainda mais dura com relação aos trabalhadores e à entidade. Logo após a compra da Azaléia pela Vulcabrás as mudanças começaram. Na fábrica de Itapetinga, por exemplo, foi implantada uma esteira que ligava os layouts (células de produção). Se antes as células operavam com base na meta definida pela empresa, organizando pausas para o banheiro e para o descanso, isso passava a ficar mais difícil já que o tempo passou a ser determinado exclusivamente pela velocidade da esteira, que deveria estar sempre abastecida de componentes e de tênis.

De fato, a situação do sindicato e dos trabalhadores ficou mais delicada, ao assumir o controle da Azaléia a Vulcabrás implantou não somente uma política de relações ainda mais duras com sindicatos e trabalhadores, como acentuou uma tendência que já se manifestava, que era o processo de internacionalização da produção calçadista nos territórios do novo operariado em direção à países que possuíam uma mão de obra ainda mais barata, como China e Índia. Isto representou o fechamento de metade das unidades da Azaléia no Sudoeste da Bahia entre 2010, no desemprego de milhares de trabalhadores, bem como a ineficácia das políticas de incentivos fiscais do Governo do Estado da Bahia, em longo prazo, frente às dinâmicas estruturais de mundialização do capital. Trataremos desta realidade nos territórios do novo operariado em publicações futuras.

\section{Referências}

Revista RBBA $\mid$ Revista Binacional Brasil Argentina 

NO ESTADO DA BAHIA

VAZQUEZ P. S.; VAZQUEZ V. S. Gênero, Trabalho e Saúde. A experiência das Mulheres do Setor Calçadista na Bahia. Salvador: Fast Dsign, 2007.

SARLET, E. D. Os 40 anos de Calçados Azaléia S.A.: 1958-1998. Canoas - RS: La Salle Gráfica BAHIA. Governo do Estado da Bahia. Secretaria da Indústria e Comércio do Estado da Bahia. Relatório de Atividades, 1998.

BAHIA. Governo do Estado da Bahia. Estatística dos Municípios Baianos. [CD-ROM]. Salvador-BA: Secretaria do Planejamento, Ciência e Tecnologia; SEI, 2001. Configuração mínima recomendada: Petium 166, 32 MB.

RIBEIRO, P. Acidente Gera Denuncia de Falta de Segurança. Correio da Bahia, Salvador, 29/02/2008.

BAHIA. Governo do Estado da Bahia. Secretaria de Saúde do Estado da Bahia; Superintendência de Vigilância e Proteção da Saúde; Centro de Estudos da Saúde do Trabalhador. Documento Técnico $\mathrm{n}^{\circ}$ 32/2000. Mapeamento Preliminar de Riscos da Empresa azaléia Calçados Nordeste S/A. Salvador, janeiro de 2001.

GALVÃO, A. Neoliberalismo e Reforma Trabalhista no Brasil. Rio de Janeiro: Revan; FAPESP, 2007. TRÓPIA, Patrícia Vieira. A adesão da Força Sindical ao neoliberalismo. In: Idéias. Campinas, ano 9, nº 1, IFCH-UNICAMP, 2002.

GALVÃO, A.; TRÓPIA, Patrícia Vieira; MARCELINO, Paula. As Bases Sociais das Novas Centrais Sindicais Brasileiras. São Paulo: Editora APRIS, 2015.

FERRAZ, C. L. O Novo Operariado Brasileiro: um estudo a partir de dois segmentos de trabalhadores. Tese de Doutorado em Ciência Política (Unicamp). Campinas, 2008.

RIBEIRO, Perla. Acidente Gera Denuncia de Falta de Segurança. Correio da Bahia, Salvador, 29/02/2008.

RAMALHO, J. R. Trabalho e sindicato em antigos e novos territórios produtivos: comparações entre o ABC e o Sul Fluminense. São Paulo: Anna Blume, 2007.

Transcrição de entrevista realizada com Robervaldo Medrado, Itapetinga, 14-05-2007.

Transcrição de entrevista realizada com Tenório Lima. Vitória da Conquista, 30-06-2008.

Transcrição de entrevista realizada com ex-operário da Azaléia. Itapetinga, 14-05-2006.

Notas 


\begin{abstract}
${ }^{\text {i }}$ A Azaléia é a líder do mercado nacional de calçados femininos e pretende a dar um salto de competitividade na área de calçados esportivos, o produto principal da fábrica baiana. Segundo dados de 1999, suas fábricas espalhadas pelo Brasil somavam 170 mil metros quadrados de área construída e geravam direta e indiretamente 16 mil empregos. A previsão é de que quando estiver funcionando plenamente, a sua filial baiana (na verdade sua rede de unidades produtivas) gere cerca de 10.000 empregos diretos, com investimentos da ordem de 205 milhões de dólares (SARLET, 1999, p. 76-77; BAHIA. Governo do Estado da Bahia, 1998).
\end{abstract}

\title{
Sobre o autor
}

Cristiano Ferraz é Doutor em Ciência Política pela Universidade Estadual de Campinas - UNICAMP; Mestre em Educação pela Universidade Federal Fluminense - UFF, sendo Graduado em História pela Universidade Estadual do Sudoeste da Bahia - UESB, instituição da qual é, atualmente, docente do Departamento de História. Publicou diversos artigos e capítulos de livro sobre teoria das classes sociais, trabalho e sindicalismo.

Endereço eletrônico: clf.ferraz@ gmail.com 